\title{
表面設計基礎講座 (第VI講)
}

色材, 68〔7〕，445-451 (1995)

\section{化 成 処 理}

傍田保*

\section{1.はじめに}

金属材に防錆性や潤滑性を付与するために，また，金 属材の塗装の前処理として化成処理が実施される。適用 される化成処理の種類は, 適用素材, 用途, 要求される 品質の他, 経済性により選択される。本稿では特に塗装 下地用途を中心として各種化成処理をとりあげる。それ ぞれの皮膜に要求される特性, 皮膜機能を高める技術や 多種の金属材を同時処理する技術などを概説する。ま た, 自動車塗装用りん酸塩処理とアルミニウム食品午塗 装用ジルコニウム処理については, 皮膜の構造解析や皮 膜の改質効果についての最近の議論を紹介する。

塗装下地としての化成処理皮膜を設計するためには, 皮膜と塗膜との界面密着性に留意する必要があるが, こ の界面密着力を簡便に評価する方法がなかった。そこ で, 筆者が考案した新しい皮膜／塗膜界面密着性評価方 法を紹介する。また，本法により前掲の皮膜改質が皮 膜／塗膜界面密着性に及ぼす影響を調べた結果を報告し て私見を述べる。

\section{2. 化成処理の種類}

各種金属材に適用される化成処理の種類と目的を表-1 に示す。

\section{1 りん酸塩処理}

1869 年, G. Ross の発明になる鉄鋼のりん酸塩処理 に始まり, 自動車塗装のための最近の $\mathrm{Ni}-\mathrm{Mn}$ 変性りん 酸西鉛皮膜処理などまで，対象素材，目的，処理方式に 応じたりん酸塩処理技術の発展と，用途別に期待される

平成 7.3.29 受理

Chemical Conversion Coating

Tamotsu SoBATA

*日本ペイント(株)表面処理事業部

大阪府寝屋川市池田中町 19-17（干 572）

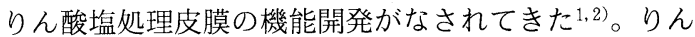
酸塩処理の種類を表-2 に示す。また，りん酸塩処理の 基本的な反応は表-3 に示すとおりである。

りん酸塩皮膜の塗装下地としての必須の要件は塗膜の 密着性を向上させ, 塗装後の耐食性が要求品質を満たす 事である。耐食性品質の要求レベルが高くない場合に は, 処理コス卜, 作業性等で有利なりん酸鉄皮膜処理が 採用される。一方, 高耐食性が要求される場合は, りん 酸覀鉛皮膜処理が採用される。

環境対応型の粉体塗装の下地処理としては, 塗膜厚が 40〜80 $\mu$ と厚く塗膜の内部応力七ズミが残るために，一 般的には素地密着性の良い薄膜夕イプのりん酸亜鉛皮膜 が採用される。特に，ポリエチレン粉体塗装のように， 塗膜形成のために被塗物が $250^{\circ} \mathrm{C}$ 以上に加熱される場 合には，耐熱性を有するカルシウム変性のりん酸亜鉛皮 膜処理が採用されている3)。

高度の塗装耐食性が要求され, かつ, 車体設計に多種 の素材が採用されている自動車塗装には, ニッケル, マ ンガンで変性されたりん酸亜鉛皮膜処理が採用されてい る。当該処理については, 3 項で詳述する。

自動車車体の軽量化を目的として，アルミニウム合金 板が鋼板や亜鉛鋼板と共に, 車体材料として採用される ようになった。この 3 種金属に対し, 自動車塗装下地品 質を満たす皮膜を形成する技術が開発され実用化されて

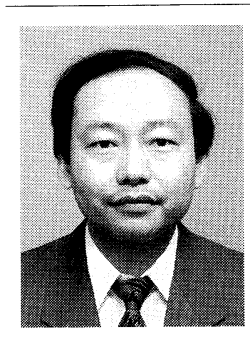

〔氏名〕そばたたもつ

〔現職〕日本ペイント(侏)表面処理事業部 第 1 技術部 課長部員

〔趣味〕園芸

〔経歴〕昭和 24 年 1 月大阪府生まれ。 昭和 46 年 3 月大阪市立大学理学 部卒。同年 4 月 日本ペイント 入社, 入社以来現在まで金属表 面処理分野の薬剂開発を主に担 当。 
表-1

\begin{tabular}{|c|c|c|}
\hline 金 属 材 & 化 成 処 理 & 目 的 \\
\hline 鉄 & $\begin{array}{l}\text { りん酸塩処理 } \\
\text { クロム酸塩処理 } \\
\text { 酸化鉄処理 }\end{array}$ & $\begin{array}{l}\text { 塗装下地 } \\
\text { 塑性加工 } \\
\text { 防錆 } \\
\text { 耐摩粍 }\end{array}$ \\
\hline 亜 & $\begin{array}{l}\text { りん酸塩処理 } \\
\text { クロ酸塩処理 } \\
\text { 硫化物処理 } \\
\text { 塗布型処理 }\end{array}$ & $\begin{array}{l}\text { 塗装下地 } \\
\text { 防錆 }\end{array}$ \\
\hline アルミニウム & $\begin{array}{l}\text { りん酸塩処理 } \\
\text { クロム酸塩処理 } \\
\text { ジルコニ処理 } \\
\text { 有機無機複合処理 } \\
\text { (塗布型) }\end{array}$ & $\begin{array}{l}\text { 塗装下地 } \\
\text { 塑性加工 } \\
\text { 防錆 }\end{array}$ \\
\hline マグネシウム & $\begin{array}{l}\text { クロム酸塩処理 } \\
\text { りん酸塩処理 }\end{array}$ & $\begin{array}{l}\text { 塗装下地 } \\
\text { 防錆用 }\end{array}$ \\
\hline ステンレス & $\begin{array}{l}\text { シュウ酸塩処理 } \\
\text { 塗布型処理 }\end{array}$ & $\begin{array}{l}\text { 塑性加工 } \\
\text { 塗装下地 }\end{array}$ \\
\hline
\end{tabular}

いる。前掲の $\mathrm{Ni}, \mathrm{Mn}$ 変性りん酸覀鉛皮膜処理技術 に, 処理液中に濃化すると処理性を劣化させるアルミニ ウムイオンを沈港化，系外に除去する技術を複合化させ たものである4,5)。

また筆者らは，アルミニウム合金よりも，軽量化効果 の大きいマグネシウム合金に対し塗装下地として，クロ メート皮膜と同等以上の高耐食性りん酸西鉛皮膜を形成 する技術，すなわち，マグネシウム合金の耐食性に阻害 要因となるニッケルイオンを含まず，マンガン濃度を高 めた $\mathrm{Mn}$ 変性りん酸业鉛処理液を提案している ${ }^{6)}$ 。

\section{2 クロム酸塩処理}

クロム酸塩処理はアルミニウム材や亜鉛材に古くから 採用されてきた。アルミニウム材のクロム酸塩処理はア ルカリクロメート法と酸性クロメート法があり, 品質的 にも経済的にも有利な酸性クロメート法が広く採用され ている7)。酸性クロメートの種類としては, クロミウム クロメートとりん酸クロメートがある。高度の耐食性が 要求される場合はクロミニウムクロメートが採用され, 高度の密着性が要求される場合や, クリヤー塗装下地と してはりん酸クロメートが採用される。

酸性クロメート皮膜の構造を図-1に, 酸性クロメー 卜の基本的な反応を表-3 に示す。

クロミウムクロメート皮膜は生成時には親水性を示す
表-2

\begin{tabular}{|c|c|c|}
\hline & 皮膜組成 & 皮膜量 \\
\hline りん酸鉄 & $\begin{array}{l}\mathrm{FePO}_{4} \cdot \mathrm{nH}_{2} \mathrm{O} \\
\mathrm{r}-\mathrm{Fe}_{2} \mathrm{O}_{3}\end{array}$ & $0.3 \sim 0.9 \mathrm{~g} / \mathrm{m}^{2}$ \\
\hline りん酸亜鉛 & $\begin{array}{l}\mathrm{Zn}_{3}\left(\mathrm{PO}_{4}\right)_{2} \cdot 4 \mathrm{H}_{2} \mathrm{O} \\
\mathrm{Zn}_{2} \mathrm{Fe}\left(\mathrm{PO}_{4}\right)_{2} \cdot 4 \mathrm{H}_{2} \mathrm{O}\end{array}$ & $\begin{array}{rl}1 \sim 3 & \mathrm{~g} / \mathrm{m}^{2} \\
3 \sim 10 & \\
10 \sim 40 & \end{array}$ \\
\hline $\begin{array}{l}\mathrm{Ni}, \mathrm{Mn} \text { 変性 } \\
\text { りん酸亜鉛 }\end{array}$ & $\begin{array}{l}\mathrm{Zn}_{3-\times}(\mathrm{Ni}, \mathrm{Mn})_{\times} 4 \mathrm{H}_{2} \mathrm{O} \\
\mathrm{Zn}_{2} \mathrm{Fe}\left(\mathrm{PO}_{4}\right)_{2} \cdot 4 \mathrm{H}_{2} \mathrm{O}\end{array}$ & $1 \sim 3 \mathrm{~g} / \mathrm{m}^{2}$ \\
\hline $\begin{array}{l}\mathrm{Ca} \text { 変性 } \\
\text { りん酸业鉛 }\end{array}$ & $\begin{array}{l}\mathrm{Zn}_{2} \mathrm{Ca}\left(\mathrm{PO}_{4}\right)_{2} \cdot 2 \mathrm{H}_{2} \mathrm{O} \\
\mathrm{Zn}_{3}\left(\mathrm{PO}_{4}\right)_{2} \cdot 4 \mathrm{H}_{2} \mathrm{O} \\
\mathrm{Zn}_{2} \mathrm{Fe}\left(\mathrm{PO}_{4}\right)_{2} \cdot 4 \mathrm{H}_{2} \mathrm{O}\end{array}$ & $3 \sim 10 \mathrm{~g} / \mathrm{m}^{2}$ \\
\hline $\begin{array}{l}\text { りん酸 } \\
\text { マンガン }\end{array}$ & $\mathrm{Mn}_{5} \mathrm{H}_{2}\left(\mathrm{PO}_{4}\right)_{2} \cdot \mathrm{nH}_{2} \mathrm{O}$ & $10 \sim 40 \mathrm{~g} / \mathrm{m}^{2}$ \\
\hline
\end{tabular}

が経時で疎水化する傾向が強いこと, $130^{\circ} \mathrm{C}$ 以上の加熱 でクラックが発生する ${ }^{8)}$ 等の特性から塗装密着性が問題 になる場合もある。りん酸ク口ム皮膜も経時で疎水化す る傾向があるものの, 塗装密着性は良好である。

りん酸クロム皮膜は皮膜中に 6 価クロムを含まないの で食品缶用塗装下地剤として広く採用されてきた。しか し，処理液には 6 価クロムを含んでおり，環境適応性を 考慮してノンクロムタイプの処理方法に代替され，今で はノンクロム処理が主流になっている。また, キャップ 材用途のアルミニウムコイルでも, 洗浄排水を出さない 塗布型ノンクロム処理が採用されている。

亜鉛材, 亜鉛メッキ鋼板のクロム酸塩処理の種類とし ては, 反応型クロメート処理法と塗布型クロメート法が ある。反応型クロメート皮膜の組成は表-3 に示す反応 で形成される成分を主成分として, さらに素地から溶解 した亜鉛の不溶化物 $\mathrm{ZnCr}_{2} \mathrm{O}_{7}$ が取り込まれる

クロメート皮膜の塗装密着性にとって亜鉛素材表面に 偏析したアルミニウムは阻害要因であり, 素材表面設 計, クロメート処理剤設計に留意を要する ${ }^{9)}$ 。

亜鉛材, 亜鉛メッキ鋼板用クロメート皮膜の期待機能 は，腐蝕環境にさらされる塗膜下で亜鉛素地の溶解を抑 制することであり，腐蝕生成物を安定錆にすることにあ る。亜鉛材の腐蝕抑制には, 緻密で非導電性の Zn $(\mathrm{OH})_{2}$ を主成分とする安定錆が導電性の $\mathrm{ZnO}$ に変化 するのを抑制するのが良いとされている10)。しかし, 反 応型クロメート皮膜による塗装密着性, 塗装耐食性の向 上には限界があり, 後述の塗布型による有機無機複合ク ロメート皮膜が，そのニーズに応えている。 
表-3

\begin{tabular}{|c|c|c|c|c|}
\hline 化成皮膜種 & 対象金属 & 金属溶解反応 & 皮膜析出反応 & 促進反応 \\
\hline \multirow[t]{2}{*}{ リン酸亜鉛 } & 鉄鋼 & $\begin{array}{l}\mathrm{Fe}+2 \mathrm{H}_{3} \mathrm{PO}_{4} \rightarrow \\
\quad \mathrm{Fe}\left(\mathrm{H}_{2} \mathrm{PO}_{4}\right)_{2}+\mathrm{H}_{2}\end{array}$ & $\begin{aligned} 3 \mathrm{Zn}\left(\mathrm{H}_{2} \mathrm{PO}_{4}\right)_{2} \rightarrow & \mathrm{Zn}_{3}\left(\mathrm{PO}_{4}\right)_{2}+4 \mathrm{H}_{3} \mathrm{PO}_{4} \\
2 \mathrm{Zn}\left(\mathrm{H}_{2} \mathrm{PO}_{4}\right)_{2}+ & \mathrm{Fe}\left(\mathrm{H}_{2} \mathrm{PO}_{4}\right)_{2} \rightarrow \\
& \mathrm{Zn}{ }_{2} \mathrm{Fe}\left(\mathrm{PO}_{4}\right)_{2}+4 \mathrm{H}_{3} \mathrm{PO}_{4}\end{aligned}$ & $\begin{array}{l}\mathrm{H}_{2}+1 / 2 \mathrm{O}_{2} \rightarrow \mathrm{H}_{2} \mathrm{O} \\
4 \mathrm{Fe}\left(\mathrm{H}_{2} \mathrm{PO}_{4}\right)_{2}+\mathrm{O}_{2} \rightarrow \\
\quad 4 \mathrm{FePO}_{4}+4 \mathrm{H}_{3} \mathrm{PO}_{4}+2 \mathrm{H}_{2} \mathrm{O}\end{array}$ \\
\hline & 亜鉛 & $\begin{array}{l}\mathrm{Zn}+2 \mathrm{H}_{3} \mathrm{PO}_{4} \rightarrow \\
\quad \mathrm{Zn}\left(\mathrm{H}_{2} \mathrm{PO}_{4}\right)_{2}+\mathrm{H}_{2} \\
\end{array}$ & $3 \mathrm{Zn}\left(\mathrm{H}_{2} \mathrm{PO}_{4}\right)_{2} \rightarrow \mathrm{Zn}_{3}\left(\mathrm{PO}_{4}\right)_{2}+4 \mathrm{H}_{3} \mathrm{PO}_{4}$ & $\mathrm{H}_{2}+1 / 2 \mathrm{O}_{2} \rightarrow \mathrm{H}_{2} \mathrm{O}$ \\
\hline \multirow{2}{*}{$\begin{array}{l}\text { 変性 } \\
\text { リン酸亜鉛 }\end{array}$} & 鉄鋼 & $\begin{array}{l}\mathrm{Fe}+2 \mathrm{H}_{3} \mathrm{PO}_{4} \rightarrow \\
\quad \mathrm{Fe}\left(\mathrm{H}_{2} \mathrm{PO}_{4}\right)_{2}+\mathrm{H}_{2}\end{array}$ & \multirow{2}{*}{$\begin{aligned} 2 \mathrm{Zn}\left(\mathrm{H}_{2} \mathrm{PO}_{4}\right)_{2}+ & \mathrm{Ca}\left(\mathrm{H}_{2} \mathrm{PO}_{4}\right)_{2} \rightarrow \\
& \mathrm{Zn}{ }_{2} \mathrm{Ca}\left(\mathrm{PO}_{4}\right)_{2}+4 \mathrm{H}_{3} \mathrm{PO}_{4} \\
2 \mathrm{Zn}\left(\mathrm{H}_{2} \mathrm{PO}_{4}\right)_{2}+ & \mathrm{Ni}\left(\mathrm{H}_{2} \mathrm{PO}_{4}\right)_{2} \rightarrow \\
& \mathrm{Zn}{ }_{2} \mathrm{Ni}_{(}\left(\mathrm{PO}_{4}\right)_{2}+4 \mathrm{H}_{3} \mathrm{PO}_{4} \\
2 \mathrm{Zn}\left(\mathrm{H}_{2} \mathrm{PO}_{4}\right)_{2}+ & \mathrm{Mn}\left(\mathrm{H}_{2} \mathrm{PO}_{4}\right)_{2} \rightarrow \\
& \mathrm{Zn}_{2} \mathrm{Mn}_{(}\left(\mathrm{PO}_{4}\right)_{2}+4 \mathrm{H}_{3} \mathrm{PO}_{4}\end{aligned}$} & $\begin{array}{l}\mathrm{H}_{2}+1 / 2 \mathrm{O}_{2} \rightarrow \mathrm{H}_{2} \mathrm{O} \\
4 \mathrm{Fe}\left(\mathrm{H}_{2} \mathrm{PO}_{4}\right)_{2}+\mathrm{O}_{2} \rightarrow \\
\quad 4 \mathrm{FePO}_{4}+4 \mathrm{H}_{3} \mathrm{PO}_{4}+2 \mathrm{H}_{2} \mathrm{O}\end{array}$ \\
\hline & 亜鉛 & $\begin{array}{l}\mathrm{Zn}+2 \mathrm{H}_{3} \mathrm{PO}_{4} \rightarrow \\
\quad \mathrm{Zn}\left(\mathrm{H}_{2} \mathrm{PO}_{4}\right)_{2}+\mathrm{H}_{2}\end{array}$ & & $\mathrm{H}_{2}+1 / 2 \mathrm{O}_{2} \rightarrow \mathrm{H}_{2} \mathrm{O}$ \\
\hline $\begin{array}{l}\text { リン酸 } \\
\text { マンガン }\end{array}$ & 鉄鋼 & $\begin{array}{l}\mathrm{Fe}+2 \mathrm{H}_{3} \mathrm{PO}_{4} \rightarrow \\
\mathrm{Fe}\left(\mathrm{H}_{2} \mathrm{PO}_{4}\right)_{2}+\mathrm{H}_{2}\end{array}$ & $5 \mathrm{Mn}\left(\mathrm{H}_{2} \mathrm{PO}_{4}\right)_{2} \rightarrow \mathrm{Mn}_{5} \mathrm{H}_{2}\left(\mathrm{PO}_{4}\right)_{4}+6 \mathrm{H}_{3} \mathrm{PO}_{4}$ & $\mathrm{H}_{2}+1 / 2 \mathrm{O}_{2} \rightarrow \mathrm{H}_{2} \mathrm{O}$ \\
\hline \multirow[b]{2}{*}{ リン酸鉄 } & & $\begin{array}{l}\mathrm{Fe}+2 \mathrm{H}_{3} \mathrm{PO}_{4} \rightarrow \\
\mathrm{Fe}\left(\mathrm{H}_{2} \mathrm{PO}_{4}\right)_{2}+\mathrm{H}_{2}\end{array}$ & $3 \mathrm{Fe}\left(\mathrm{H}_{2} \mathrm{PO}_{4}\right)_{2} \rightarrow \mathrm{Fe}_{3}\left(\mathrm{PO}_{4}\right)_{2}+4 \mathrm{H}_{3} \mathrm{PO}_{4}$ & \multirow[t]{2}{*}{$\mathrm{H}_{2}+1 / 2 \mathrm{O}_{2} \rightarrow \mathrm{H}_{2} \mathrm{O}$} \\
\hline & 鉄鋼 & $\begin{array}{r}2 \mathrm{Fe}+4 \mathrm{NaH}_{2} \mathrm{PO}_{4}+ \\
2 \mathrm{H}_{2} \mathrm{O}+\mathrm{O}_{2} \rightarrow \\
2 \mathrm{Fe}\left(\mathrm{H}_{2} \mathrm{PO}_{4}\right)_{2}+4 \mathrm{NaOH}\end{array}$ & $\begin{array}{l}2 \mathrm{Fe}\left(\mathrm{H}_{2} \mathrm{PO}_{4}\right)_{2}+2 \mathrm{NaOH}+1 / 2 \mathrm{O}_{2} \rightarrow \\
\quad 2 \mathrm{FePO}_{4}+2 \mathrm{NaH}_{2} \mathrm{PO}_{4}+3 \mathrm{H}_{2} \mathrm{O} \\
2 \mathrm{Fe}\left(\mathrm{H}_{2} \mathrm{PO}_{4}\right)_{2}+6 \mathrm{NaOH}+1 / 20_{2} \rightarrow \\
\mathrm{Fe}(\mathrm{OH})_{3}+2 \mathrm{Na}_{2} \mathrm{HPO}_{4}+2 \mathrm{NaH}_{2} \mathrm{PO}_{4}+\mathrm{H}_{2} \mathrm{O} \\
2 \mathrm{Fe}(\mathrm{OH})_{3} \rightarrow \mathrm{Fe}_{2} \mathrm{O}_{3}+3 \mathrm{H}_{2} \mathrm{O}\end{array}$ & \\
\hline \multirow{3}{*}{$\begin{array}{l}\text { クロミウム } \\
\text { クロメート }\end{array}$} & \multirow{2}{*}{ アルミ } & \multirow[t]{2}{*}{$\begin{array}{l}\mathrm{A} 1+3 \mathrm{HF} \rightarrow \\
\quad{\mathrm{A} 1 \mathrm{~F}_{3}+3 / 2 \mathrm{H}_{2}}\end{array}$} & $\begin{array}{l}3 / 2 \mathrm{H}_{2}+\mathrm{CrO}_{3} \rightarrow \mathrm{Cr}(\mathrm{OH})_{3} \\
\mathrm{Cr}(\mathrm{OH})_{3}+\mathrm{CrO}_{3} \rightarrow \mathrm{Cr}(\mathrm{OH})_{2} \mathrm{HCrO}_{4}\end{array}$ & \multirow[t]{2}{*}{$3 / 2 \mathrm{H}_{2}+\mathrm{CrO}_{3} \rightarrow \mathrm{Cr}(\mathrm{OH})_{3}$} \\
\hline & & & $\begin{array}{l}\mathrm{AlF}_{3}+2 \mathrm{H}_{2} \mathrm{O} \rightarrow \mathrm{AlO}(\mathrm{OH})+3 \mathrm{HF} \\
\mathrm{AlO}(\mathrm{OH})+\mathrm{H}_{2} \mathrm{O} \rightarrow \mathrm{A} 1(\mathrm{OH})_{3}\end{array}$ & \\
\hline & 亜鉛 & $\begin{array}{l}\mathrm{Zn}+\mathrm{H}_{2} \mathrm{SO}_{4} \rightarrow \\
\mathrm{ZnSO}_{4}+\mathrm{H}_{2}\end{array}$ & $\begin{array}{l}3 / 2 \mathrm{H}_{2}+\mathrm{CrO}_{4}{ }^{2-}+\mathrm{H}_{2} \mathrm{O} \rightarrow \\
2 \mathrm{Cr}(\mathrm{OH})_{3}+\mathrm{CrO}_{4}{ }^{2-} \rightarrow \\
\quad \mathrm{Cr}(\mathrm{OH})_{3}+2 \mathrm{OH}^{-} \\
\quad \mathrm{OH})_{3} \cdot \mathrm{Cr}(\mathrm{OH}) \cdot \mathrm{CrO}_{4}+2 \mathrm{OH}^{-}\end{array}$ & $\begin{array}{l}3 / 2 \mathrm{H}_{2}+\mathrm{CrO}_{4}^{2-}+\mathrm{H}_{2} \mathrm{O} \rightarrow \\
\mathrm{Cr}(\mathrm{OH})_{3}+2 \mathrm{OH}^{-}\end{array}$ \\
\hline $\begin{array}{l}\text { リン酸 } \\
\text { クロム }\end{array}$ & アルミ & $\begin{array}{l}\mathrm{A} 1+3 \mathrm{HF} \rightarrow \\
\quad{\mathrm{A} 1 \mathrm{~F}_{3}+3 / 2 \mathrm{H}_{2}}\end{array}$ & $\begin{array}{l}3 / 2 \mathrm{H}_{2}+\mathrm{CrO}_{3} \rightarrow \mathrm{Cr}(\mathrm{OH})_{3} \\
\mathrm{Cr}(\mathrm{OH})_{3}+\mathrm{H}_{3} \mathrm{PO}_{4} \rightarrow \mathrm{CrPO}_{4}+3 \mathrm{H}_{2} \mathrm{O} \\
\mathrm{A} 1 \mathrm{~F}_{3}+2 \mathrm{H}_{2} \mathrm{O} \rightarrow \mathrm{A} 10(\mathrm{OH})+3 \mathrm{HF} \\
2 \mathrm{~A} 10(\mathrm{OH}) \rightarrow \mathrm{A}_{2} \mathrm{O}_{3}+\mathrm{H}_{2} \mathrm{O}\end{array}$ & $3 / 2 \mathrm{H}_{2}+\mathrm{CrO}_{3} \rightarrow \mathrm{Cr}(\mathrm{OH})_{3}$ \\
\hline $\begin{array}{l}\text { リン酸 } \\
\text { ジルコニウム }\end{array}$ & アルミ & $\begin{array}{l}\mathrm{A} 1+\mathrm{H}_{3} \mathrm{PO}_{4} \rightarrow \\
{\mathrm{A} 1 \mathrm{PO}_{4}+3 / 2 \mathrm{H}_{2}}\end{array}$ & $\begin{array}{l}\mathrm{AlPO}_{4}+\left(\mathrm{NH}_{4}\right)_{2} \mathrm{ZrF}_{6} \rightarrow \\
\mathrm{ZrFPO}_{4}+\mathrm{AlF}_{3}+2 \mathrm{NH}_{4} \mathrm{~F}\end{array}$ & \\
\hline
\end{tabular}

\section{3 ジルコニウム処理}

アルミニウム材のノンクロム処理材としてジルコニウ 厶処理が実用化されている。チタン系処理も報告されて いるが11,12)，主流はジルコニウム系処理である。N．J. Newhard は，りん酸を含まないジルコニウム系処理に ついて皮膜の構造を図-2 のように推定している ${ }^{13)}$ 。塗 装密着性, 塗装耐食性で良好な品質を示すりん酸ジルコ
二ウム処理について表-3に示すような皮膜形成反応が 推定されている。りん酸ジルコニウム皮膜の品質改良技 術については 3 項で詳述する。

\section{4 塗布型処理}

化成処理は，化学反応により金属材表面に変換皮膜を 形成する方法であるが、反応で副生するスラッジ，有害 重金属を含む洗浄排水の問題等を解消するために，金属 


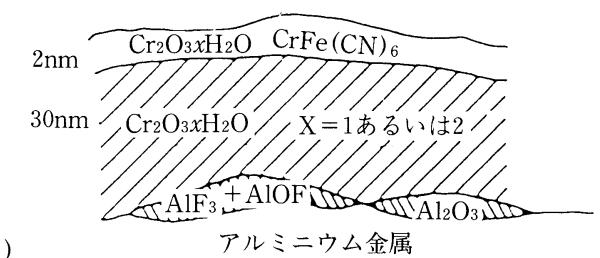

(a)

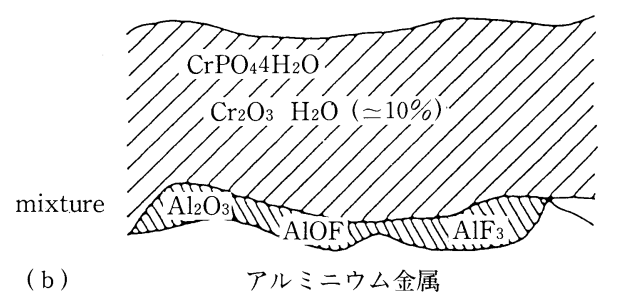

図-1 クロメート皮膜の構造

(a) クロム酸クロメート

(b) リン酸クロメート

材に処理剤を塗布し, 水洗することなく乾燥し皮膜形成 する塗布型処理方法が採用されるようになり, 今では,

塗布型処理も広義に化成処理に含まれている。

塗布型処理剂は，金属材に化学的に密着した皮膜を形 成し, また，処理後のリンスを不要とする配合設計がな されている。また, 皮膜に高度の耐食性や密着性を, あ るいは特殊機能を付与するために処理剤の設計がなされ てきた。

业鉛材, 亜鉛メッキ鋼板, ステンレス鋼材には主とし て塗布型クロメート処理が採用されている。例えば, 部 分還元クロム酸水溶液に, $\mathrm{SiO}_{2}$ やポリアクリルヒドロ キシアミド15), アクリルエマルジョン16), アクリル系マ イクロゲルエマルジョン17)などの水溶性有機樹脂を配合 し, 皮膜の可とう性を改善した有機無機複合型クロメー 卜処理液が実用化されている ${ }^{18)}$ 。また, 自動車防錆鋼板 のように, 下層にクロメート皮膜, 上層に有機複合シリ ケート皮膜の複層構造皮膜を形成する処理方法も実施さ れている ${ }^{19)}$ 。窪田らは，有機無機複合被覆鋼板における シリカの防食機構について, 亜鉛の腐蝕時に緻密で安定 な腐蝕生成物（塩基性炭酸亜鉛）を形成するのにシリカ が寄与すると報告している20)。

アルミニウム材用塗布型ノンクロム処理については, 畑中らがポリアクリル酸一ジルコニウム系の皮膜につい て皮膜の生成機構やりん酸クロム皮膜に対比して加工後 密着性, 耐食性の優位性を報告している21)。

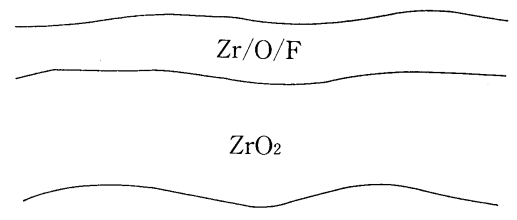

$\mathrm{Al}_{2} \mathrm{O}_{3}$

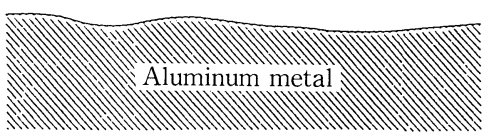

図-2 ノンクロムジルコン系化成皮膜の構造（ $\mathrm{PO}_{4}$ フリー)

また，アルミニウムコイル表面に特殊機能を付与する 塗布型処理剤の例をあげれば, 熱交換器用のアルミニウ ムフィン用親水化処理剤として, アルカリ金属シリケー ト，アミノアルコールおよび水溶性樹脂を含有する無臭 性の親水化処理剤が特許公告されている22)。

\section{3. 皮膜改質技術と最近の議論}

\section{3. $1 \mathrm{Ni}-\mathrm{Mn}$ 変性りん酸西鉛皮膜処理技術}

自動車車体の高防錆ニーズに応えるために, 前処理, 塗装の各方面からの技術開発, 改良がなされてきた。自 動車の下塗り塗装では高防錆のカチオン型電着塗装が採 用された。当該塗装方法によると, 被処理物界面は $\mathrm{pH}$ 12 以上の熱アルカリにさらされる23)ために, 下地被膜 機能として耐アルカリ性が要求される。また, 自動車用 素材では，高防錆の各種覀鉛メッキ鋼板が採用されるな かで, 鋼板では問題にならなかった塗膜の耐水二次密着 性の改善が, 下地被膜に要請された。このような二ーズ に応えるべく開発され, 実用化されているのが Ni-Mn 変性りん酸覀鉛皮膜処理である。当該処理では鉄系素材 には Phosphophyllite を亜鉛系, アルミニウム系素材 には $\beta$-Hopeite をそれぞれに耐アルカリ性皮膜を形成 して, 自動車塗膜の品質設計の向上に役立っている。

渡辺らは, りん酸亜鉛処理液成分の Ni イオンが結晶 の微粒化作用を有し, 鋼板のアノード腐蝕抵抗性を高め ると報告している ${ }^{24)}$ 。島倉は, 処理液成分の $\mathrm{Ni}$ イオン がりん酸亜鉛処理時の鋼板の自然電極電位を貴な方向に シフトさせる効果に着目し, Ni イオンを含まないりん 酸車鉛処理液で, 処理液浸漬時の鋼板の電位を貴方向に 制御することにより, $\mathrm{Ni}$ イオンを含むりん酸亜鉛処理 液と同様に，微粒化した結晶性皮膜でアノード腐蝕抵抗 性の高い皮膜を得る方法を報告している ${ }^{25)}$ 。 


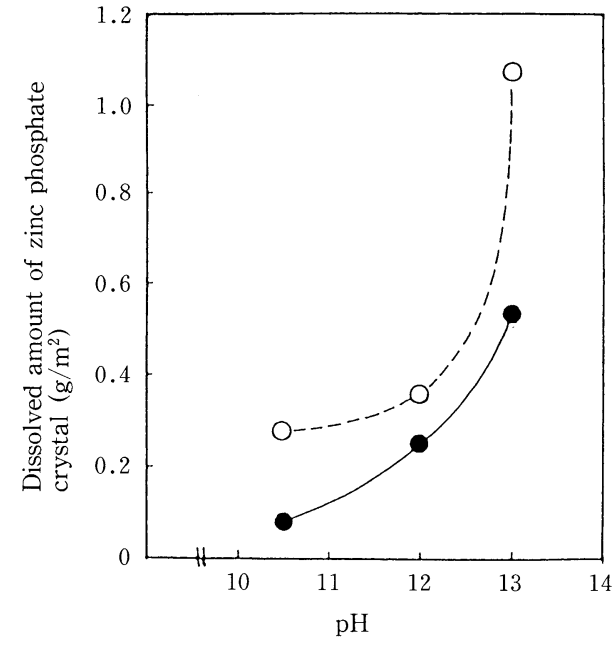

図-3 Chemical stability of each zinc phospate crystal without $\mathrm{Mn}$ composition in alkaline region (26)

: Phospophyllite on cold rolled steel $\bigcirc$ : Hopeite on galvannealed steel

佐藤らは, Mn により, りん酸亜鉛皮膜の耐アルカリ 性を改質できることを報告している。Hopeite 結晶を主 成分とする皮膜が, Phosphophyllite を主成分とする 皮膜に比べて耐アルカリ性に劣ること ${ }^{26)}, \mathrm{Mn}$ で変成さ れた Hopeite は改質され, Phospophyllite 並の耐アル カリ性を示すようになることを報告している27,28)。ま た, 電子スピン共鳴法 (ESR), レーザーラマン分光 法, 拡張 X 線構造 (EXAFS) 等の構造解析手法によ り $\mathrm{Mn}$ 変性りん酸亜鉛皮膜の結晶構造28) 報告してい る。

$\mathrm{Mn}$ 変性りん酸再鉛皮膜による亜鉛メッキ鋼板の耐水 二次密着性向上効果について, 吉岡らは, 結晶水の脱水 復水に着目し, 皮膜中の $\mathrm{Ni}, \mathrm{Mn}$ 含有率の高い皮膜は 二水塩から四水塩への復水変化が遅く（皮膜の体積変 化, 構造変化) 耐水二次密着性が良好となると推定して (る29)。

一方, 前田は前掲の復水説よりも, Van, Ooij らの 説30)を支持し, 亜鉛メッキ鋼板の耐水二次密着性の劣化 を塗膜下で塩基性の $\mathrm{Zn}(\mathrm{OH})_{2}$ が生成すること，すな わち, 塩基性塗膜との酸塩基作用が失われる結果密着欠 損が発生するとしている ${ }^{31)}$ 。

筆者は， $\mathrm{Ni} ， \mathrm{Mn}$ がりん酸亜鉛皮膜を改質しカチ才 ン型電着塗膜との界面密着力を高めること, また, 耐水

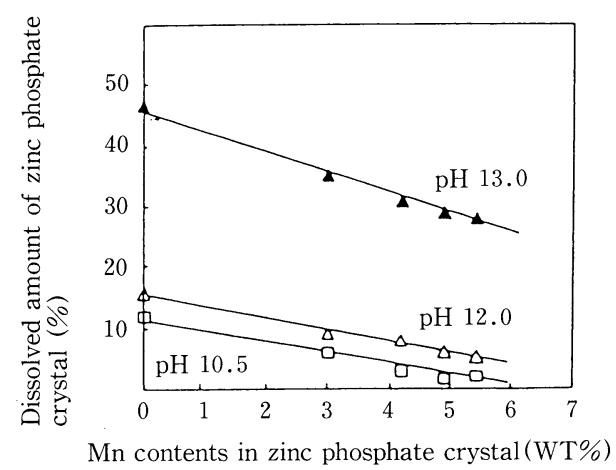

図-4 Chemical stability of each Mn-modified zinc phosphate crystal in alkaline solution (28)

二次密着性に劣る Hopeite 皮膜でも $\mathrm{Cr}$ リンスにより皮 膜／塗膜界面密着力が著しく向上することを確認した。 詳細を 4 項で報告する。

\section{$3.2 \mathrm{~V}, \mathrm{Ce}$ 变性りん酸ジルコニウム処理技術}

アルミニウム製缶のノンクロム塗装下地として，りん 酸ジルコニウム皮膜はりん酸クロム皮膜に十分代替でき る塗装密着性品質を有していた。しかし、近年の缶形状 の複雑化と塗装缶の深絞り加工がなされるに及んでは, リン酸クロム皮膜並の密着性レベルの向上が求められ, また, 処理液の経時による組成変動で生成皮膜の密着性 品質の劣化が問題になっていた。 $\mathrm{V}, \mathrm{Ce}$ 変性りん酸シ ルコニウム処理技術はかかるニーズに応えるものとして 開発された。

熊谷らは, ジルコニウム皮膜とエポキシフェノール系 塗膜との密着機構を高分子鎖の官能基とジルコニウム, りん酸ジルコニウム化合物との相互作用や，触媒作用の 存在で説明している。更に, 処理液中にアルミニウムイ オンが蓄積すると $\mathrm{AL}$ 含有率の高い皮膜が生成し塗装 密着性を劣化させると報告している32)。

池田らは, ジルコニウム処理液に V (バナジウムイ オン）を配合することにより, 塗装密着性の高い皮膜を 形成できること, 当該皮膜の XPS 分析により皮膜中の $\mathrm{V}$ の存在, 皮膜表層のアルミニウム化合物の減少を確 認している ${ }^{33)}$ 。ジルコニウム皮膜の密着性向上には，ア ルミニウム化合物のような塩基性でなく, $\mathrm{V} や \mathrm{Ce}^{34)}$ 等 の多価金属のような酸性サイドの化合物からなる皮膜が 有効であるとしている。

筆者は, Ceがりん酸ジルコニウム皮膜を改質しエポ 
試験方法

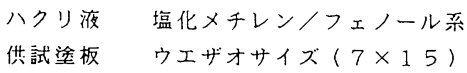

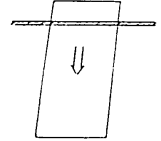
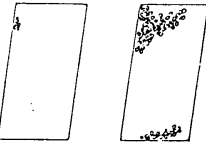

[ B ]
塗膜ハクリ抵抗性 $=[\mathrm{A}]-[\mathrm{B}]$

図-5 塗膜ハクリ抵抗性試験

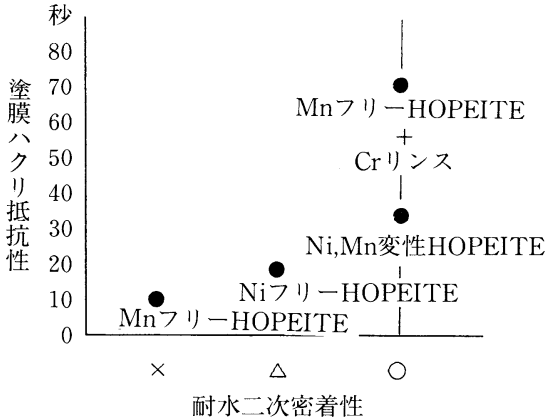

$\begin{array}{lll}\text { 素 } & \text { 材 } & \text { 合金化溶融亚鉛メッキ鋼板 } \\ \text { 被 膜 } & \text { 各種りん酸亜鉛被膜 } \\ \text { 塗 膜 } & \text { 自動車塗装系 } 3 \text { コート } \\ \text { ハクリ剂 } & \text { 塩化メチレンノフェノール系 }\end{array}$

図-6 りん酸覀鉛皮膜処理鋼板の力チオン電着塗装 系で塗膜ハクリ抵抗性と耐水二次密着性が相関 する。

キシフェノール系塗膜との界面密着力を高めることを確 認した。詳細を 4 項で報告する。

\section{4. 新しい皮膜／塗膜界面密着性評価技術}

金属材の塗膜密着性，塗装後耐食性は皮膜／塗膜界面 密着性に影響され，時に支配要因になっている場合も少 なくない。皮膜／塗膜界面密着力を短時間で簡便に測定 する方法を確立できれば，化成皮膜の各種機能設計に極 めて有用である。筆者は塗膜のハクリ剂を利用する塗膜 ハクリ抵抗性試験を考案し，塗膜ハクリ抵抗性が皮膜／ 塗膜界面密着力の代用特数值になることを確認した。

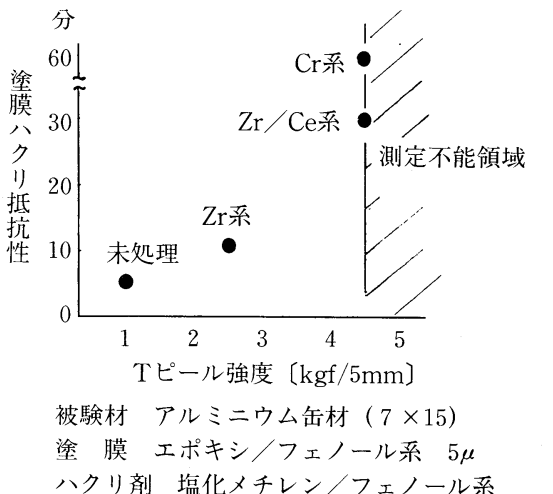

図-7 食午用アルミニウム塗装板の塗膜ピール強度 之塗膜ハクリ抵抗性が相関する。

\section{1 塗膜ハクリ抵抗性試験}

塗膜ハクリ剂として市販の塩化メチレンノフェノール 系ハクリ剂を使用し，図-5 のように供試塗板にハクリ 剤を塗布したのち，ハクリ所要時間を求める。筆者は, 本試験による塗膜のハクリ機構について下記 3 点より, 塗膜内部に塩化メチレンが浸透して, 皮膜／塗膜界面に 達して始めて塗膜の膨潤力が実質的に皮膜／塗膜界面に 作用し塗膜をハクリさせると推定している。(1)塗膜厚 は，ハクリ開始時間 $[\mathrm{B}]$ を長くするが，八クリ所要時 間 $[\mathrm{A}]$ - $[\mathrm{B}]$ の変化は小さい。(2)塗膜に線傷をいれて も，ハクリ開始部位が特定されず，ハクリ所要時間に及 ぼす影響も小さい。(3)塗膜ハクリ抵抗性試験後の皮膜 （自動車用りん酸亜鉛皮膜）を電子顕微鏡で観察して も，皮膜結晶にダメージを認めない。

\section{2 評価事例と考察}

本法で, 食缶用アルミニウム塗装板の塗膜ピール強度 と塗膜八クリ抵抗性，および自動車塗装鋼板の耐水二次 密着性と塗膜ハクリ抵抗性が相関する事を確認した。ま た，素材がプラスチックであるが，塗膜八クリ抵抗性試 験の評価事例として，ポリプロピレン製バンパー塗膜の ピール強度と塗膜ハクリ抵抗性の相関データを示した。

食缶用アルミニウム塗装板の事例ではセリウムで変成 したリン酸ジルコニウム皮膜が，塗膜密着性を向上させ ているが, リン酸クロム皮膜の密着性レベルには至って いないことがわかる。自動車用りん酸要鉛処理鋼板（合 金化溶融亜鉛メッキ鋼板）の事例では $\mathrm{Ni} ， \mathrm{Mn}$ による 皮膜の改質により，また， Cr リンスにより皮膜／塗膜 界面密着力を高め, 塗膜の耐水二次密着性を向上させた といえる。本試験結果と， Cr リンスすると復水傾向を 


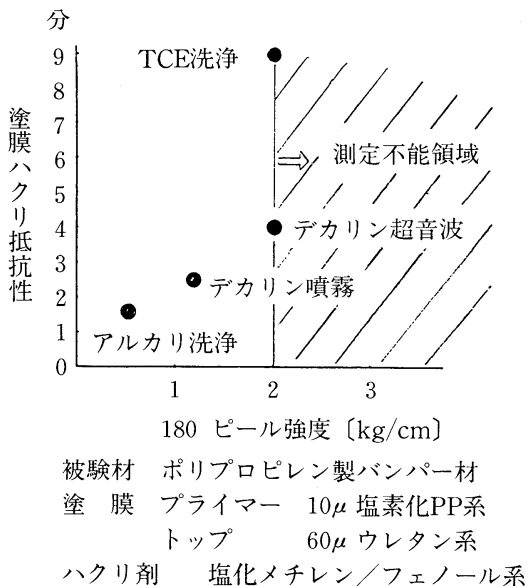

図-8 ポリプロピレン製バンパー塗膜のピール強度 と塗膜ハクリ抵抗性が相関する。

示す Hopeite でも良好な耐水二次密着性を示す等の知 見をあわせ考慮すると，亜鉛メッキ鋼板の耐水二次密着 性の制御には，復水による体積変化を制御するよりも皮 膜／塗膜界面密着力強化の方が有効である。

\section{5. おわりに}

化成処理の目的は次工程の目的を達成するために, 最 適機能を有する化成処理皮膜を適用素材表面に形成する ことである。それゆえ適用素材や次工程の仕様変更の度 に，化成処理の適合性が検討され，しばしば仕様の変更 が必要となる。化成処理の技術開発は，そうしたニーズ に応えることで進められてきたといえる。今，社会的 ニーズから，上り環境に優しい材料と方法からなる化成 処理方法が求められているし，より省資源，省工程を可 能とする化成処理技術が求められている。そうしたニー ズに応える塗装下地皮膜の設計には, 皮膜と塗膜との界 面密着力が現行皮膜に比べて十分なものかを判断する必 要がある。筆者が提案する新しい皮膜／塗膜界面密着性 評価方法がその一助となれば幸いである。

\section{引用文献}

1）森谷忠吾 : 塗装工学, 15, $18 （ 1980 ）$
2）松島安信 : 実務表面技術，35，2（1988）

3）後藤一生 : 塗装工学, 15, 357 (1980)

4) M. A. Kuehner : SAE 740099 (1974)

5) 特開平3-191071号

6) 特開平6-330341号

7）安原清忠 : 軽金属, 40，753（1990）

8）金子秀昭：実務表面技術，35，283（1988）

9）前田重義 : 塗装工学, 20，277（1985）

10）岡 襄二, 高杉政志, 山本一雄 : 鉄と鋼, 63, A 57 (1982)

11）藤本 健, 木山晃男：アルミニウム研究会誌, 10, 56 (1981)

12）藤本 健, 木山晃男, 金井富義, 岩井一郎 : アル ミニウム研究会誌，10，58（1981）

13) N. J. Newhard. JR. : Meet. Corros control (USA), 225 (1978)

14）USP 674015（特公昭56-33468号）

15）中澤眞人，米野 實：鉄と鋼，77，414（1991）

16）武津博文, 和泉圭二, 内田幸夫 : 材料とプロセ ス, 4, 610 (1991)

17）伊東威安，吉田佑一：材料とプロセス，4，626 (1991)

18）加藤忠一：表面技術，45，1226（1994）

19）塩田俊明：色材，67，659（1994）

20）窪田隆広，山下正明：鉄と鋼，81，76（1995）

21）畑中孝一, 福井正信, 向井良和, 豊瀬喜久郎 : 軽 金属，40，298（1990）

22）特公平 5-88870号

23）前田重義，浅井恒敏，岡田秀弥：防食技術，31, 268 (1982)

24）渡辺ともみ，石田 裕：金属表面技術，39，683 (1988)

25）島倉俊明：TECHNO COSMOS，2，30（1992）

26）佐藤 登, 南 達郎, 河野博文: 金属表面技術, 38, 571 (1987)

27）佐藤 登: 金属表面技術，37，758（1986）

28）佐藤 登：表面技術，45，259（1994）

29）吉岡克昭，吉田佑一，渡辺ともみ：鉄と鋼， 72, 1125 (1986)

30) J. Van Ooij, et al. : Surf. Interf. Anal., 17, 403 (1991)

31）前田重義 : Zairyo-to-Kankyo, 43, 448 （1994）

32）熊谷正夫，池田 哲：金属表面技術，38，564 (1987)

33）池田 哲, 目黒重行 : 近畿アルミニウム表面処理 研究会会誌 NO 143，1（1990）

34）特公平 6-11915号 